\title{
Lack of Energy Efficiency Legislation in the Malaysian Building Sector Contributes to Malaysia's Growing GHG Emissions
}

\author{
Suzaini M. Zaid ${ }^{1}$, Nik Elyna Myeda ${ }^{2}$, Norhayati Mahyuddin ${ }^{3}$, Raha Sulaiman ${ }^{4}$ \\ ${ }^{1}$ Faculty of the Built Environment, University of New South Wales, Sydney, Australia \\ ${ }^{1,2,3,4}$ Faculty of Built Environment, University of Malaya, Kuala Lumpur, Malaysia
}

\begin{abstract}
Malaysia's carbon emissions grew by $+235.6 \%$ from 1990 to 2005 , largely due to an increase in national energy demand of $210.7 \%$ from 1990 to 2004 . This unparalleled carbon emission growth, along with business-as-usual (BAU) practices will put Malaysia at high risk for carbon lock-in and a very unsustainable path of development. Malaysia clearly needs to make significant and urgent changes in its policy, economy, industries and lifestyle in order to reduce its climate change impacts. In 2010 Malaysia announced a voluntary commitment to reduce $40 \%$ of its greenhouse gases (GHG) emissions by 2020 (from 1990 levels). Without emissions mitigation and conservation policies, Malaysia is unlikely to meet its emissions reduction targets. Presently, Malaysia has no energy efficiency legislation in its growing building sector. This paper reviews existing building policies and energy efficiency measures in Malaysia and highlights the need to implement mandatory energy efficiency building codes in reducing the sector's impact on climate change.
\end{abstract}

\section{Introduction}

Malaysia's voluntarily commitment to reduce $40 \%$ of its greenhouse gas (GHG) emissions (from 1990 levels) by year 2020, announced at the 2009 United Nations Climate Change Conference in Copenhagen (COP-15) [1]. However, this commitment has not been greeted with much optimism given limited support from existing legislation and restrained environmental awareness [1]. Currently, there is no legislation that holds environmental sustainability mandatory for major GHG emitting sectors such as energy, transportation, and oil and gas [1]. Malaysia has rapidly transformed from an agricultural to an industrialized economy in the last four decades, with an alarming growth of GHG emissions that are caused by the escalating number of automobiles, factories and power plants.

Research using a long-range energy alternative planning system (LEAP) projected that without any mitigation measures, Malaysia's carbon dioxide (CO2) emission in 2020 will amount to 285.73 million tonnes; a 68.86\% increase compared to year 2000 [2]. In 2010, the International Energy Agency (IEA) reported Malaysia's carbon emission was a total of 185 million tonnes, which is approximately $0.6 \%$ of the global total (30,276 million tonnes of CO2) [3] (IEA, 2012). Between 1990 to 2004, Malaysia's carbon emissions grew by 221 percent $(+221 \%)$ increased energy demand from industrial and transportation sectors, dubbed the fastest growth rate in the world [4, 5]. By 2009, 
Malaysia's national energy demand had increased by $210.7 \%$ from 1990 , which prompted its carbon emissions growth by $+235.6 \%[6,7]$.

The building sector's primary contribution of GHG emissions is the result of fossil fuels being used to generate electricity or used directly for building operations, in the form of fuel combustions [7-9], produces $40 \%$ of global wastes, and consumes approximately $16 \%$ of water sources [10-12]. Residential buildings represent $65 \%$ of the global total sectoral emissions, and $35 \%$ for commercial buildings [13]. Only $10-20 \%$ of building energy is consumed for pre-production and demolition or deconstruction, and similarly for its GHG emissions $[10,14]$. The bulk of GHG emissions from the building sector are largely produced in the operational phase (80-90\%) from energy consumption for heating, cooling, lighting, ventilation and appliances [10,14]. Approximately 50\% of final building energy used during operation is consumed for space heating and cooling, and between $10 \%$ to $20 \%$ is used for water heating [14]. Furthermore, the bulk of the building sector's GHG emission comes from residential buildings, accounting for approximately $65 \%$ of the global total, while commercial buildings account for the balance of $35 \%$ (in 2000) [13]. Studies suggest that without any action, the building sector 's energy use is expected to grow from $60 \%$ to $90 \%$ between 2005 to 2050 [14], thus increasing its GHG emissions. The building sector's contribution to climate change can be summarized and tabulated as Error! Reference source not found..

Table 1: Building Sector's Global Contribution to Climate Change [14-16]

\begin{tabular}{|c|c|c|c|c|}
\hline \multicolumn{5}{|c|}{ Building Sector Account for: } \\
\hline \multirow{3}{*}{$40 \%$} & \multirow{3}{*}{$\begin{array}{l}\text { Of global energy } \\
\text { use }\end{array}$} & \multirow{3}{*}{$\begin{array}{c}\text { Consumes } 60 \% \text { of global } \\
\text { electricity }\end{array}$} & \multirow{2}{*}{$\begin{array}{c}80-90 \% \text { Used } \\
\text { during Operational } \\
\text { Phase }\end{array}$} & $\begin{array}{l}50 \% \text { Used for space } \\
\text { heating and/or cooling }\end{array}$ \\
\hline & & & & $\begin{array}{l}10-20 \% \text { Used for water } \\
\text { heating }\end{array}$ \\
\hline & & & \multicolumn{2}{|c|}{$\begin{array}{l}10-20 \% \text { Used for pre-production and demolition/ } \\
\text { deconstruction }\end{array}$} \\
\hline \multirow{2}{*}{$40 \%$} & \multirow{2}{*}{$\begin{array}{l}\text { Of global GHG } \\
\text { emissions }\end{array}$} & $\begin{array}{l}65 \% \text { from Residential } \\
\text { buildings }\end{array}$ & \multirow{2}{*}{\multicolumn{2}{|c|}{ 80-90\% Emitted during Operational Phase }} \\
\hline & & $\begin{array}{l}35 \% \text { from Commercial } \\
\text { buildings }\end{array}$ & & \\
\hline
\end{tabular}

\section{The Carbon Lock-In Effect}

A 'carbon lock-in' condition is manifested through "a combination of systematic forces that perpetuate fossil fuel-based infrastructure in spite of their known environmental externalities and the apparent existence of cost-neutral, or even cost-effective, remedies" [17]. As developing countries prepare for a growing demand for construction, it is important to invest in more energy efficient buildings and prevent the 'carbon lock-in' effect. Industrialized countries' significant contribution to climate change is predominantly a result of meeting consumer's demands for goods and services such as transportation, electricity, industrial and commercial buildings, through carbon-based energy technologies and systems $[17,18]$. According to the World Bank, in China alone it is estimated that every year lost in failure to build efficient buildings locks in approximately 800 million square meters of urban built space of inefficient energy use for decades into the future [19]. Inefficient sectors and infrastructure prolong the operation of obsolete technologies that are highly energy dependent, which causes large-scale 'carbon lock-in' [20]. The danger of lock-in pattern is highly relevant to climate change and environmental policies, as high GHG emissions become more difficult to reverse [21].

The challenge now is to absorb rapidly and on a large-scale, low-carbon technologies into the economy and move beyond research and development (R\&D) strategies into operation [20]. The inertia to change and reduce energy-dependency manifests itself as market and policy failure that is systematically ignored, or aggravated institutionally [17, 22]. Environmental policy makers need to develop policies in mainstreaming energy efficient strategies, which are based on best practice and 
case study energy performance. Nevertheless, carbon lock-in is not a permanent condition, rather a persistent state that raises market and policy barriers to alternatives [17]. Malaysia should be strategic in implementing policies that support mainstream implementation of new technological advances to avoid or minimize the lock-in effect. Figure 1 presents a contemporary comparison of Malaysia's steady increase of carbon emissions (metric tons per capita) to the world average emissions and other developing countries in Asia such as China, India and Indonesia, and comparing Malaysia's emission with its neighbouring Singapore where there has been a steady decrease in emissions [23]. The unparalleled carbon emission growth, coupled with business-as-usual practices will potentially lock Malaysia in for an unsustainable path of development.

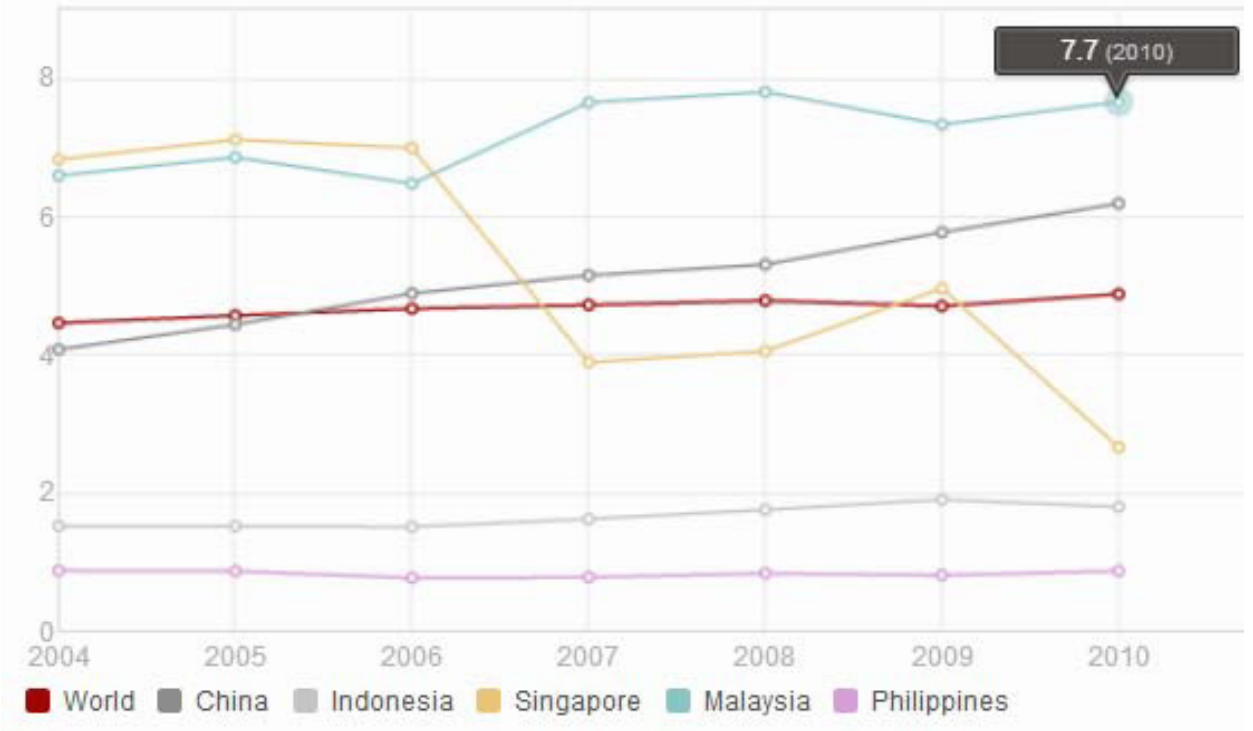

Figure 1: Carbon Emissions in Metric Tons per Capita [23]

Many projects have therefore emerged in the building sector to reduce energy consumption. It is estimated that consumption in both new and existing buildings could be reduced significantly by applying existing technologies, design, equipment, management systems and alternative solutions [24]. The IPCC predicts a reduction of $75 \%$ in energy consumption for new buildings, through incorporating energy efficiency strategies in designing and operating buildings systematically [24]. Holistic and systematic approaches to building systems, rather than improving individual component efficiency, is predicted to achieve significant energy reduction [14].

Notwithstanding its environmental impacts, the building sector has been identified by the Intergovernmental Panel on Climate Change (IPCC) as the sector with largest mitigation potential [18]. It is estimated that both new and existing buildings have the potential to reduce energy consumption up to $80 \%$ using proven and commercially available technologies and with net profit during their lifespan $[18,25]$. Enforcing energy performance requirements in building codes has been argued to be the most cost-effective strategy in reducing GHG emissions from both existing and new buildings [25]. In 2007, GHG emissions from Malaysian buildings accounted for approximately 4\% of national emissions related to energy, at 3,947 Gigagram of carbon dioxide $\left(\mathrm{GgCO}_{2}\right)$ or approximately 0.004 Giga-tonnes of carbon dioxide $\left(\mathrm{GtCO}_{2}\right)$ [26]. The average energy consumption and GHG emissions for the Malaysian building sector is expected to grow approximately at $6 \%$ rate annually [27]. Zain-Ahmed estimated that the average Malaysian office building consumes energy at approximately 269 kilowatt per meter square per year $\left(\mathrm{kWh} / \mathrm{m}^{2} /\right.$ year) [28]. Table 2 summarizes the building sector's potential reduction in terms of energy consumption, GHG emissions, water consumption and waste production. 
Table 2: Building Sector's Reduction Potential $[14,15,16]$

\begin{tabular}{|l|c|}
\hline \multicolumn{2}{|c|}{ Building Sector Reduction Potential: } \\
\hline $\mathbf{7 5 \%}$ & Reduction in energy consumption \\
\hline $\mathbf{3 5} \%$ & Reduction in GHG emissions \\
\hline $\mathbf{4 0 \%}$ & Reduction in water consumption \\
\hline $\mathbf{7 0} \%$ & Reduction in waste production \\
\hline
\end{tabular}

\section{Lack of Energy Efficiency Legislation Contributing to National GHG Emissions Growth}

The Malaysian building sector and construction industry is yet to streamline and upgrade its conventional approach to innovative building systems and energy efficiency [29]. For example, the Construction Industry Development Board (CIDB) missed an opportunity to promote energy efficiency in the Construction Industry Master Plan (2006-2015), which was launched in 2007 [30]. Poor quality of construction, maintenance and performance of contractors remain the central challenges affecting the industry [29, 31]. Most environmental problems in Malaysia are caused by "lack of environmental considerations in the exploitation, development and management of resources as well as lack of control of pollution resources" [32].

Malaysia presently has no energy efficiency strategies enforceable in the mandatory Uniform Building By-Laws (UBBL) to provide minimum energy efficiency and/or energy performance standards for buildings [33]. In addition, sectoral baseline data for energy-related GHG emissions in Malaysia is limited or at best underdeveloped [34]. Presently, there is no consistent framework in Malaysia for assessing GHG emissions from buildings, which limits the development of an emissions baseline for the building sector and therefore building energy performance policies. This is reflected in the existing Malaysian Green Building Index (GBI) rating tool, which exclude any calculation for GHG emissions from buildings.

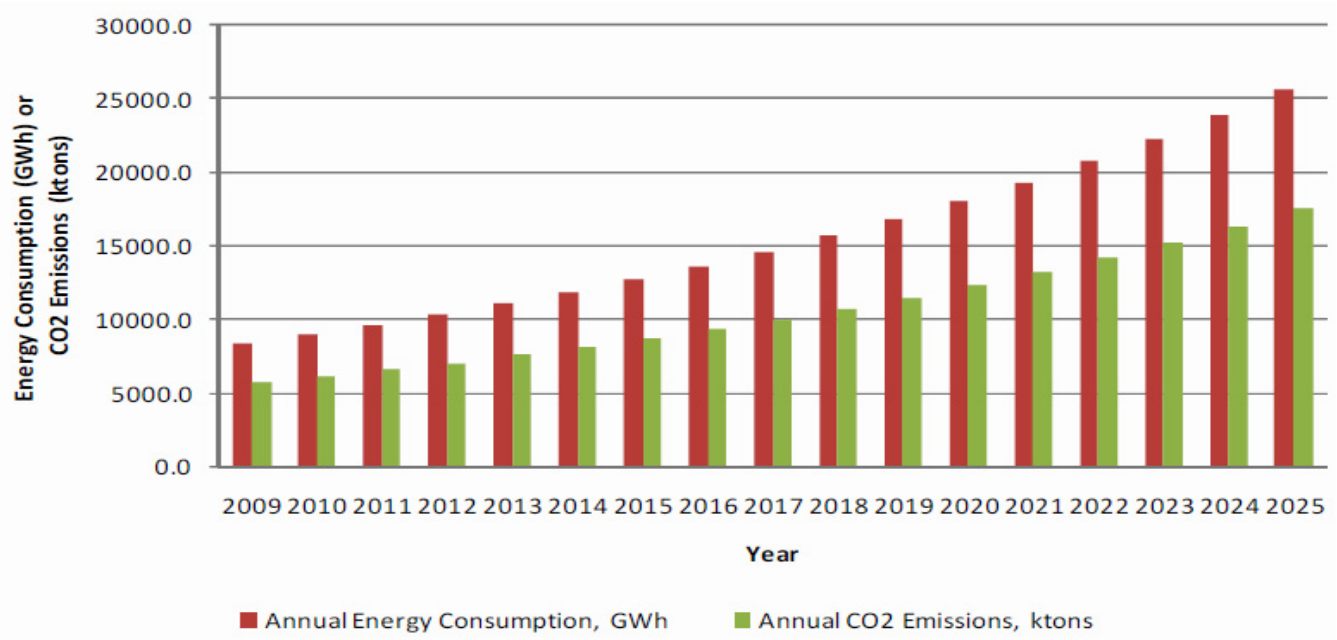

Figure 2: Business-As-Usual (BAU) Forecast of Annual Energy Consumption and $\mathrm{CO}_{2}$ Emissions for Malaysian Building Sector [27]

In reference to energy efficiency (EE) for the building sector in Malaysia, the Malaysian voluntary Standard Code of Practice on Energy Efficiency and Use of Renewable Energy for Nonresidential Buildings (MS 1525:2007) was introduced in 2005 (and updated in 2007) [33]. Energy efficiency for residential buildings in Malaysia is neither regulated nor promoted [27], which is likely 
to have significant implications for its energy end-use performance [38]. Without such legislation to reduce the sector's energy consumption, its GHG emissions growth is inevitable and puts the country at high risk for carbon lock-in with more inefficient buildings being constructed. Energy efficiency performance standards would help reduce total GHG emissions from electricity consumed by the building sector.

It is also crucial for stakeholders in the building industry to promote existing guidelines to reduce its overall environmental impact. Additionally, the industry must be able to change and expand innovatively, in order to meet shifting demands and growing international standards [29, 39]. This voluntary code of practice is to guide effective use of energy (including renewable energy) in new and existing non-residential buildings, to reduce energy consumption within the construction, operation and maintenance of a building [37]. At present, a similar energy efficiency guideline for the residential sector does not exist. Therefore neither the mandatory or voluntary standards consider the impact of building energy use on climate change.

According to United Nations Development Programme (UNDP) report on Malaysia's Building Sector Energy Efficiency Project (BSEEP), in 2008, Malaysia's building sector consumed approximately 7,750 GWh of electricity and emitted 5,301 ktoe of GHG [27]. By 2009, the sector's energy consumption increased to 8,315 GWh and its GHG emissions to 5,688 ktoe [27]. The increase between 2008 and 2009 was higher than expected, at a rate of approximately $7.3 \%$ for both the sector's energy consumption and GHG emissions. The forecast predicts an increase of GHG emissions to 8,088 ktons and energy consumption to $11,824 \mathrm{GWh}$ by 2014 (refer Error! Reference source not found. 2).

\section{Voluntary Energy Efficiency Approaches In Malaysian Building Sector}

Existing government policies and legislation have been poorly formulated in dealing with energy efficiency in buildings, and efforts to incorporate the MS1525:2007 into the Uniform Building ByLaws (UBBL) have been stalled since 2003 [27]. The MS 1525:2007 stipulates energy efficiency standards and recommendations for renewable energy application for new non-residential buildings and retrofit of existing buildings [36]. EE requirements made in the MS 1525:2007 are such as efficient lighting systems, efficient air-conditioning and mechanical ventilation systems, and designing an energy management system [36]. The scope of the MS 1525:2007 guideline is divided into seven categories: architectural and passive design strategy, building envelope, lighting, electrical power and distribution, air-conditioning and mechanical ventilation (ACMV) system, an energy management control system, and building energy simulation method [36].

The MS 1525:2007 recommends an annual energy consumption rate for non-residential buildings at $135 \mathrm{kWh} / \mathrm{m}^{2} /$ year $[28,35,36]$. However, similar energy efficiency or energy performance standard for the Malaysian residential sector does not exist [33, 37], and the existing MS 1525:2007 is focused on non-residential buildings with air-conditioning systems whereas not all residential buildings would consume high levels of energy for air-condition. Energy efficiency standard for the residential sector should also cater for the different operating time between residential buildings that is mainly occupied during the night, in comparison to a non-residential or commercial building that is highly occupied during the daytime.

As the average non-residential building in Malaysia consumes between $250-300 \mathrm{kWh} / \mathrm{m}^{2} /$ year, it implies that more drastic strategies are needed to comply with the energy efficiency guideline. Localized climatic design strategy can be seen in the architectural and passive design strategy and building envelope categories, which combines architectural, engineering, site planning and landscaping multidisciplinary approach in designing a more energy efficient building [36]. The architectural and passive design strategies include site planning and orientation, natural day-lighting, natural ventilation, façade design and material, and strategic landscaping [36]. Building envelope category stipulates minimum standards for OTTV, shading co-efficiency, day-lighting, maximum 
thermal transmittance (U-value) for roofs and RTTV for air-conditioned buildings, and air leakages [36]. A similar code of practice for residential buildings is absent. Notwithstanding the measures and efforts already in place, the most critical gap still lies in the lack of energy efficiency or energy standards for residential buildings in Malaysia. Even more so, there is lack of energy efficiency or conservation measures for existing residential buildings in Malaysia. This is also reflected in the Malaysian Green Building Index (GBI), which excludes existing residential buildings in its assessment.

The GBI currently only applies to non-residential buildings (existing and new), residential buildings (new only), industrial (new and existing), and newly included townships [40]. The GBI remains a voluntary tool and has yet to introduce the rating tool for existing residential buildings. This presents an apparent gap in research practice and the need for policy development, particularly for existing residential buildings, in terms of energy efficiency or energy performance standard for building operations. The GBI Residential certification presents a general scorecard based on a pointsystem calculation that measures the relevant design features. This certification, which is not administrated by the government, does not imply any energy standard nor does it ensure best practice on energy efficiency. The GBI's energy efficient (EE) assessment criteria for new residential buildings are divided into five categories, i.e. minimum energy performance, renewable energy, advanced energy efficiency performance based on Overall Thermal Transfer Value (OTTV) and Roof Thermal Transfer Value (RTTV), home office and connectivity, and sustainable maintenance. The minimum EE performance criteria is based on OTTV and RTTV that is adopted in the MS 1525:2007, which sets a minimum standard of less than 50 Watts per meter square (OTTV $\left.\leq 50 \mathrm{~W} / \mathrm{m}^{2}\right)$ and less than 20 Watts per meter square (RTTV $\leq 25 \mathrm{~W} / \mathrm{m}^{2}$, respectively [41].

\section{Conclusion}

In this paper we highlighted that without building energy efficiency legislation; the building sector increases its 'carbon lock-in' risk and further contributes to the growing GHG emissions in Malaysia. The building sector has remarkable potential to reduce GHG emissions during its operational phase with strategies such as low-energy building design, energy efficiency policies and building codes. Many neighbouring countries in South East Asia have already adopted mandatory energy efficiency building codes, but Malaysia is a notable exception. The current Malaysian Uniform Building By-Laws 1984 construction standard imposes no energy efficiency requirements. This is a missed opportunity for saving energy and possible large GHG reductions by the Malaysian building sector, which in turn would help Malaysia reach is voluntary $40 \%$ reduction pledge. Therefore, it is high time for Malaysia to implement energy efficiency building codes and further encourage stakeholders to employ green building ratings systems, in order to expedite the sector's energy saving effect and raise the construction industry standards.

\section{References}

1. Department of Environment, COP 15: The Copenhagen Accord, in Quarterly DOE Update on Environment, Development and Sustainability, C.M. Chun, Editor 2010, Department of Environment (DOE), Ministry of Natural Resources and Environment: Putrajaya.

2. Safaai, N.S.M., et al., Projection of $\mathrm{CO} 2$ emissions in Malaysia. Environmental Progress \& Sustainable Energy, 2010

3. IEA, CO2 Emissions from Fuel Combustion Highlights, 2012, International Energy Agency: Paris.

4. Al-Jazeera, Malaysia Fastest Growing Polluter, in Al Jazeera English News2007, Al Jazeera.Net: Mecca. 
5. Watkins, K., Human Development Report 2007/2008, in Fighting Climate Change: Human Solidarity in a Divided World2007, The Human Development Report Office (HDRO). United Nations Development Programme: New York, NY.

6. Energy Commission, National Energy Balance, 2011, Malaysian Energy Information Hub (MEIH), Energy Commission Malaysia

7. IEA, CO2 Emissions from Fuel Combustions Highlights, in IEA Statistics 2011 Edition2011, International Energy Agency (IEA). Paris.

8. UNEP-SBCI, Common Carbon Metric: Protocol for Measuring Energy Use and Reporting Greenhouse Gas Emissions from Building Operations, in Draft for Pilot Testing2010, UNEPSBCI, UNEP-Sustainable Buildings \& Climate Initiative \& WRI, World Resource Institute.

9. UNEP-SBCI, Buildings and Climate Change: Summary for Decision-Makers, 2009, UNEPSBCI, United Nations Environment Programme - Sustainable Buildings and Climate Change Initiative: Paris.

10. Sisson, W., et al., Energy Efficiency in Buildings: Transforming the Market, 2009, World Business Council for Sustainable Development (WBCSD: Switzerland.

11. UNEP-SBCI, Final Report on Results of Phase I of the Common Carbon Metric (Draft), D. McIntire and R. Gupta, Editors. 2010, United National Environment Programme-Sustainable Buildings and Climate Initiative (UNEP-SBCI).

12. du Plessis, C., Agenda 21 for Sustainable Construction in Developing Countries, in A discussion document2002, International Council for Research and Innovation in Building and Construction (CIB). United Nations Environment Programme, International Environmental Technology Centre (UNEP-IETC): South Africa.

13. Baumert, K.A., T. Herzog, and J. Pershing, Navigating the Numbers, in Greenhouse Gas Data and International Climate Policy2005, World Resources Institute (WRI).

14. Urge-Vorsatz, D., et al., Best Practice Policies for Low Energy and Carbon Buildings. A Scenario Analysis., in Research report prepared by the Center for Climate Change and Sustainable Policy (3CSEP) for the Global Best Practice Network for Buildings2012, Central European University (CEU) and Global Buildings Performance Network (GBPN).

15. Comstock, M., et al., Building Design and Construction: Forging Resource Efficiency and Sustainable Development, 2012, United Nations Environment Programme (UNEP) - Sustainable Buildings and Climate Initiative (SBCI).

16. Levine, M., et al., Building Energy-Efficiency Best Practice Policies and Policy Packages, in Executive Summary2012, Ernest Orlando Lawrence Berkeley National Laboratory, Global Building Performance Network (GBPN) of Climateworks Foundation

17. Unruh, G.C., Understanding carbon lock-in. Energy Policy, 2000. 28(12): p. 817-830.

18. IPCC, Climate Change 2007: Synthesis Report, in An Assessment of the Intergovernmental Panel on Climate Change, Intergovernmental Panel on Climate Change (IPCC): Valencia, Spain.

19. ABC, Building Energy Efficiency: Why Green Buildings Are Key to Asia's Future, ed. M.P. Laurenzi. 2007, Hong Kong: ABC, Asia Business Council.

20. Brown, M.A., et al., Carbon Lock-In: Barriers to Deploying Climate Change Mitigation Technologies, in ORNL/TM-2007/124 (revised November 2008)2007, Oak Ridge National Laboratory: Altanta, GA.

21. Anas, A. and G.R. Timilsina, Lock-In Effects of Road Expansion on CO2 Emissions: Results from a Core-Periphery Model of Beijing, in Policy Research Working Paper 50172009, The World Bank, Development Research Group, Environment and Energy Team.

22. Unruh, G.C., Escaping carbon lock-in. Energy Policy, 2002. 30(4): p. 317-325.

23. World Bank, Carbon (CO2) Emissions in Metric Tons per Capita 2013, Carbon Dioxide Information Analysis Centre, Environmental Sciences Division, Oak Ridge National Laboratory.

24. Levine, M., et al., Residential and Commercial Buildings, in Contribution of Working Group III to the Fourth Assessment Report of the Intergovernmental Panel on Climate Change, B. Metz, et al., Editors. 2007, Cambridge University Press, Cambridge, United Kingdom 
25. UNEP, Buildings and Climate Change: Summary for Decision-Makers, 2009, UNEP-SBCI, United Nations Environment Programme - Sustainable Buildings and Climate Change Initiative: Paris.

26. Malaysia Energy Centre. GHG Inventory in the Energy Sector and Industrial Processes. in Proceedings of the 5th Workshop on Greenhouse Gas Inventories in Asia. 2007. Kuala Lumpur, Malaysia: National Institue for Environmental Studies (NIES).

27. UNDP, Building Sector Energy Efficiency Project (BSEEP), in United Nations Development Programe Project Document. Country: Malaysia 2011, United Nations Development Programme (UNDP).

28. Zain-Ahmed, A. Integrating Sustainable Energy in Buildings: A Case Study in Malaysia. in FAU Conference. 2008. Copenhagen, Denmark.

29. Hamid, Z.A. and K.A.M. Kamar. Modernising the Malaysian Construction Industry. in CIB World Congress 2010. 2010. Salford, United Kingdom.

30. CIDB, Strategic Recommendations For Improving Environmental Practices in Construction Industry, 2007, CIDB, Construction Industry Development Board.

31. EPU, Tenth Malaysia Plan, in Economic Development: Development Plans2010, Economic Planning Unit.

32. Hussein, J. and Z.A. Hamid, Issues and Challenges in Sustainable Construction in the Built Environment: Malaysiaon Construction Industry Initiatives, 2008, CIDB, Construction Industry Development Board Malaysia.

33. Zain-Ahmed, A. Contemporary Issues in Energy and Buildings in Malaysia: Focus on R\&D and Policies. in SENVAR + ISESEE 2008: Humanity + Technology. 2008. Universiti Teknologi Mara, Malaysia Universiti Teknologi Mara.

34. Fong, W.-K., H. Matsumoto, and Y.-F. Lun, Application of System Dynamics model as decision making tool in urban planning process toward stabilizing carbon dioxide emissions from cities. Building and Environment, 2009. 44(7): p. 1528-1537.

35. Shafii, F., Status of Sustainable Building in South-East Asia, in Report prepared for SB08 Melbourne2008, Institute Sultan Iskandar of Urban Habitat \& Highrise, Universiti Teknologi Malaysia: Johor, Malaysia.

36. SIRIM. Revised Malaysian Standard. MS 1525:2007 Code of Practice on Energy Efficient and use of Renewable Energy for Non-Residential Buildings (First Revision) Malaysian Standards Approved on 19/06/2007 by the Ministry of Science, Technology and Innovation in Accordance with the Standards of Malaysia Act (ACT 549) 200716 January 2011]

37. SIRIM, Malaysian Standards Catalogue 2004: Construction Materials and Building, 2004, Department of Standards Malaysia (SIRIM). Ministry of Science, Technology \& Innovations.

38. APEC, Peer Review on Energy Efficiency in Malaysia, 2011, Asia-Pacific Economic Cooperation (APEC).

39. Abdulllah, F., et al. An Overview On The Growth and Development Of The Malaysian Construction Industry. in Workshop on Construction Contract Management 2004. 2004. Universiti Teknologi Malaysia. Johor, Malaysia.

40. Greenbuildingindex, The Green Building Index, 2012, Greenbuildingindex Sdn Bhd.

41. Greenbuildingindex, GBI Assessment Criteria for Residential New Construction (RNC) in Green Building Index Version 2.02011, Greenbuildingindex Sdn Bhd (GSB): Kuala Lumpur 